Article

\title{
Impact of Environmental Pollution in the Sustainability of Architectural Heritage: Case Study from Cartagena of India, Colombia
}

\author{
Heidis Cano ${ }^{1, *}$, John Fredy Ríos-Rojas ${ }^{2}$, Joaquin Hernández-Fernández ${ }^{3}$, Wilson Bernal Herrera ${ }^{4}$, \\ Mayka Bautista Betancur ${ }^{2}$, Lorcy De La Hoz Vélez ${ }^{5}$ and Lidy Agámez González ${ }^{6}$ \\ 1 Department of Civil and Environmental, Universidad De La Costa, Barranquilla 080002, Colombia \\ 2 Department of Mechanical, Electronic and Biomedical Engineering, Antonio Nariño University, \\ Bogota 111321, Colombia; johnri@uan.edu.co (J.F.R.-R.); mayka.bautista@uan.edu.co (M.B.B.) \\ 3 Chemical Engineering Program, School of Engineering, Universidad Tecnológica de Bolivar, Parque Industrial \\ y Tecnológico Carlos Vélez Pombo km 1 Vía Turbaco, Bolívar 130001, Colombia; joahernandez@utb.edu.co \\ 4 Department of Industrial Engineering, Antonio Nariño University, Cartagena 130015, Colombia; \\ wilsonbernal@uan.edu.co \\ 5 Department of International Commerce, Antonio Nariño University, Cartagena 130015, Colombia; \\ lorcydelahoz@uan.edu.co \\ 6 Department of Social Work, Colegio Mayor of Bolívar Technologic Institute, Cartagena 130001, Colombia; \\ lagamez@colmayorbolivar.edu.co \\ * Correspondence: hcano3@cuc.edu.co or heidycano@gmail.com
}

check for updates

Citation: Cano, H.; Ríos-Rojas, J.F.; Hernández-Fernández, J.; Bernal Herrera, W.; Bautista Betancur, M.; De La Hoz Vélez, L.; Agámez

González, L. Impact of Environmental Pollution in the Sustainability of Architectural Heritage: Case Study from Cartagena of India, Colombia. Sustainability 2022, 14, 189. https://doi.org/ $10.3390 /$ su14010189

Academic Editors: Luis F.O. Silva, Hongya Niu and Claudia Casapulla

Received: 9 November 2021

Accepted: 15 December 2021

Published: 24 December 2021

Publisher's Note: MDPI stays neutral with regard to jurisdictional claims in published maps and institutional affiliations.

Copyright: (C) 2021 by the authors. Licensee MDPI, Basel, Switzerland. This article is an open access article distributed under the terms and conditions of the Creative Commons Attribution (CC BY) license (https:// creativecommons.org/licenses/by/ $4.0 /)$.

\begin{abstract}
Limited studies have been carried out in emerging nations on the correlation among the environmental pollution, economic factors, and architectural heritage. For this reason, this research presents an assessment of environmental parameter values on materials deterioration used in architectural heritage in Cartagena de Indias; furthermore, it depicts the effect of heritage degradation on socioeconomic aspects of people whose livelihood depends on trade, tourism, and service activities. Dose-response functions were used for estimating of deterioration of carbon steel, copper, and zinc caused by relative humidity $(\mathrm{RH})$, temperature $(\mathrm{T})$, sulphur dioxide deposition $\left(\mathrm{DSO}_{2}\right)$, and chloride deposition $\left(\mathrm{DCl}^{-}\right)$. In addition, socioeconomic impact on architectural heritage was studied using a Socioeconomic Impact Survey (SEIS), with the sample of 174 individuals who work in areas of great architectural value in the city. The results show a corrosion rate (Vcorr) in the range of $80<$ Vcorr $<200,2.8<$ Vcorr $<5.6$ and $4.2<$ Vcorr $<8.4 \mu \mathrm{m}$ /year for carbon steel, copper, and zinc, respectively, due to the high level of pollutants. The high deterioration jointly with the lack of citizen culture affect the architectural heritage monuments causing a negative impact in several economic aspects. The establishment of public programs is essential for the conservation of the heritage monuments of the city.
\end{abstract}

Keywords: environmental pollution; architectural heritage; sustainability; economic aspects

\section{Introduction}

Among the variables that cause architectural heritage deterioration are climate change, pollution, and environmental factors. The impact of environmental pollution is a sensible issue for both the city and the surroundings [1,2].

Sustainability is a concept that helps establish resilient systems and increases adaptability to change, durability, and the possibility to remain diverse and productive over time. It also explains the means for stabilizing human needs across time [3], and requires economic efficiency [4], a socio-ecological perspective [5], and strong environmental protection policies [6].

Historical city sites that have the UNESCO World Heritage status are significant for their impact on the economic growth of the region and contribution to the achievement 
of an inclusive and sustainable development. These sites are also an important factor for enhancing social capital and environmental protection [7].

The deterioration of different materials due to air pollution [3] seriously affects the cultural wealth of the architectural heritage $[8,9]$. Protection and conservation must be a responsibility of each state, city, or municipality [9-11]. The aggressive pollutants that increase the deterioration processes of materials are gases such as $\mathrm{SO}_{2}, \mathrm{NOx}, \mathrm{O}_{3}$, atmospheric particles (PM) [12,13], salt spray, organic acids, and polycyclic aromatic hydrocarbonsPAHs [9,14-16]. Additionally, the effect of climate (temperature, relative humidity, $(\mathrm{RH})$, precipitation and wind) [17] has a significant influence in the deterioration of materials in coastal areas [18].

Deterioration of materials caused by atmospheric corrosion is an irreversible process [19] due to different reactions that occur in the surface of materials (carbon steel, copper, bronze, limestone, etc.), and this situation has been a subject of study for different research projects in Europe. CULT-STRAT Project or Noah's Ark Project studied the strong correlation between climate and air pollution in architectural heritage in different scenarios [20-23]. These correlations can be addressed in terms of modelling and predicting as in the case of dose-response functions [20]. Dose-response functions use multivariate models for estimating the dynamics of change of the materials in terms of corrosion rate(rcorr,). Several investigations [24-26] define dose-response functions as the measure of the level of concentration, deposition of the pollutants, and meteorological parameter values to the corrosion rate of materials, represented by Equation (1):

$$
\mathrm{r}_{\text {corr, }, \mathrm{it}}=f\left(\mathrm{RH}_{\mathrm{it}}, \mathrm{T}_{\mathrm{it}}, \mathrm{D}_{\mathrm{SO} 2 \mathrm{it}}, \mathrm{DPM}_{\mathrm{it}}, \tau\right)
$$

where DPM is the particulate matter (PM), $\mathrm{D}_{\mathrm{SO} 2}$ deposition in $\left(\mathrm{mg}^{*} \mathrm{~m}^{-2} \mathrm{day}^{-1}\right.$, and $\tau$ is the exposure time (months); $\mathrm{i}$ corresponds to the $\mathrm{i}$-th corrosion station and $\mathrm{t}$ is the time period in which data were collected [27]. Some research has been established using this function, as [28-32].

Atmospheric contamination and natural processes may generate depreciation of historical monuments [16] and economic or social losses due to continuous maintenance [31,33]. Currently, The World Heritage Committee has a list of structures damaged or deteriorated, making their sustainable development extremely urgent [34]. In Italy, the corrosion risk is due to the levels of limestone (34\%) and copper (97\%) that are higher than the tolerable level, [19]; in Madrid, the corrosion due to pollution is lower compared to cities of Central and North Europe, [32], but it is necessary to carry out constant maintenance and restoration processes considering the concepts of sustainability and conservation [24].

Furthermore, the preservation and sustainability of material assets are necessary for the success of an economic model and can provide sustainable economic growth for the local people. This situation, however, might harm their heritage value [35]. The evaluation of economic aspects obtained by cultural heritage indicates the need for implementing a policy for cultural tourism [36].

Cultural tourism includes all activities done by tourists. They could be visits to museums, exhibitions, events, and fairs, among the most important [37], where the visitors want to discover new experiences and enjoy cultural attractions and products [38]. Tourism and culture are closely linked [39] and they are considered as the key elements of tourism and industry [40]. Some authors establish that cultural heritage and attractions are integrated under the concept of environmental sustainability. One of them highlights the contribution of cultural tourism towards the improvement of the quality of life in a community [41,42]. Tunbridge et al. [43] establishes that tourism as an economic source in heritage places receives little attention by Graham et al. [44] and the economic aspect around heritage has been researched little, but currently the increase of studies of heritage in business schools indicates the economic potential of heritage. This last is considered fundamental for cultural tourism [45] and can be an input to the economy of each country if properly managed [46]. In 2019, the Travel and Tourism sector contributed to $10.4 \%$ of the global GDP; a share which decreased to $5.5 \%$ in 2020 due to ongoing restrictions to mobility [47]. 
The recognition of cultural tourism as a constituent element is essential for social and economic development, and the preservation of it also improves the historical significance of a social group. Moreover, it recognizes its importance in building and developing a city regarding the social, economic, environmental, and cultural aspects [48]. The architecture of historical sites attracts more tourists and provides them with new cultural experiences. It presents the architectural heritage as an opportunity to promote several economic activities in these regions where high levels of poverty and unemployment prevail. Architectural heritage is associated with tourism development for both inhabitants and visitors [49]. There has to be a balanced relationship between those variables to protect society's culture between tradition and modernity [50]. The importance of sustainable architectural heritage depends on the basic economic aspects necessary for its valuation and preservation. The economic approach denominates heritage as a public asset. The architectural heritage presents several aspects that generate externalities, e.g., it is a fact that these sites are visited in high levels, making their maintenance and preservation difficult. This situation involves many people who get income from many indirect jobs whereas the private sectors or government contribute to the conservation. Thus, the private owners are less likely to invest in heritage.

Historical urban heritage represents a clear case of a public good with positive externalities. It indicates that the enjoyment of the assets representing this heritage is non-exclusive and allows a beneficial experience for other people or institutions [51]. Thus, it is recurrent that institutions and individuals take advantage of it without investing or financing its sustainability. High demand of this heritage, in contrast, could guarantee its preservation. Many heritages are, thus, threatened by obsolescence of their historic building and modern urban growth. Dynamic economic activities and high-income status result emigrating from these environments [52]. However, the issue estimates the potential spillover effects in the local economy, as stated by Bowitz and Ibenholt, but does not estimate the true value of culture [53]. For example, in an informal market, people generally depend on the architectural heritage and monuments for their livelihood. The low levels of formal employment for most of the unemployed urban population becomes a source of informal employment. It has less productivity, stability, and wages than formal sector employment. Several studies recommend different approaches regarding generated revenues and employment, in terms of the effects of heritage on the regional economy.

In this case, this paper focuses on the Cartagena UNESCO World Heritage, which is considered a historical city to be visited, especially for the architectural value of its buildings and urbanism. About 2.7 million national and foreign tourists arrive annually in the city to benefit from the city's integral heritage route [54]. This implies that the lack of employment in the city and the number of street vendors of varying socioeconomic levels, especially the lower class, increases mainly in the historical center of Cartagena. Since it has a high concentration of tourists, informal vendors can generate an income from selling products such as traditional handicrafts, among other consumer products or services. For example, Colombian studies on the economic impact of the historical city of Cartagena [55] list the most common products bought by tourists and locals, including arts and crafts, lodging, natural and cultural attractions, and complimentary services. The latter relates to tours, typical meals, souvenirs, brochures, and so on. There are several dynamic economic opportunities with visits to cultural heritage like museums, historical monuments, and ancient buildings. It also includes the constructions without historical content used to provide commercial services to tourists. They are public swimming pools, sports courts, viewpoints, etc. Cartagena is promoted as a city with a mixture of sun and beach with many cultural attractions. This counteracts the comparative disadvantage of its exotic beaches in comparison to other tourist sites of the Caribbean [56]. Zuleta, as cited [57], found that the architectural and cultural goods (36\% of total attractions), ethnography (25\%), scheduled events $(19 \%)$, and natural sites $(16 \%)$ represented the city's main tourist attractions. This gives Cartagena the significant potential to become a tourist city with a highly established capacity to attend to those seeking alternative attractions. 
The Tourism Corporation's report from the Coastal Airport Society SA's study (SACSA) shows the growth of national and international travelers going to this city. In 2016 there were 1,931,511 visitors, 2,201,923 in 2017, and more than 2,700,000 in 2018 [54]. This form of tourism generates direct, indirect, and induced economic impact on revenue and employment [58] as cited in [59], depending on the large percentage of tourists visiting the preserved heritage [60]. Thus, it is the city that the media presents: idealized, careful and beautiful, but internally fragmented with processes of exclusion. An informal city where spontaneous settlements are part of the hidden Cartagena. It represents the Colombian city with significant social, structural, functional, economic, and political problems [61]. Its significant historical heritage is a potential environmental asset, including its socio-cultural traditions and colorful colonial-style buildings, which bring economic and social recovery opportunities.

A study indicates that the majority of people in Cartagena consider the Historic Center's heritage as an instrument for economic development. It also indicates that a quarter of the tourists' expenses are from the attractions of the historic heritage of Cartagena.

"The study establishes that for each peso a tourist spends in the commerce sector, the city generates an additional 3.6 pesos of production. Thus, Cartagena's attractive assets represent an added value and employment generation accountable for $3.8 \%$ and $5.0 \%$, respectively of the city's figures. The historic zone creates $11.2 \%$ of the city's added value and $8.4 \%$ of its workforce" [55]. The Historical Center, its plazas, and its several museums become sufficient attractions to mobilize diverse groups of tourists from different places. Most of the economy grows as a result of these tourist attractions. It becomes risky, from an architectural heritage viewpoint, in regard to how many citizens support their economies with numerous activities like hotels, travel agencies, restaurants, and commerce in general. It also brings the potential for developing informal work in the absence of other opportunities. Historical heritage is a source of economic wealth that increases the level and quality of life for locals [62].

This study aims to determine the impact of environmental pollution in the sustainability of architectural heritage in Cartagena, Colombia. It also determines the relevant risks related to economic aspects and heritage degradation with indicators of socioeconomic impact due to the degradation of the Cartagena architectural heritage. The results can help propose effective public policies with a scientific basis to conserve the site.

\section{Materials and Methods}

\subsection{Area of Study}

Cartagena is located at $10^{\circ} 25^{\prime} \mathrm{N}, 75^{\circ} 32^{\prime} \mathrm{W}(10.41667,-75.5333)$, covering an area of $609.1 \mathrm{~km}^{2}$ (see Figure 1).

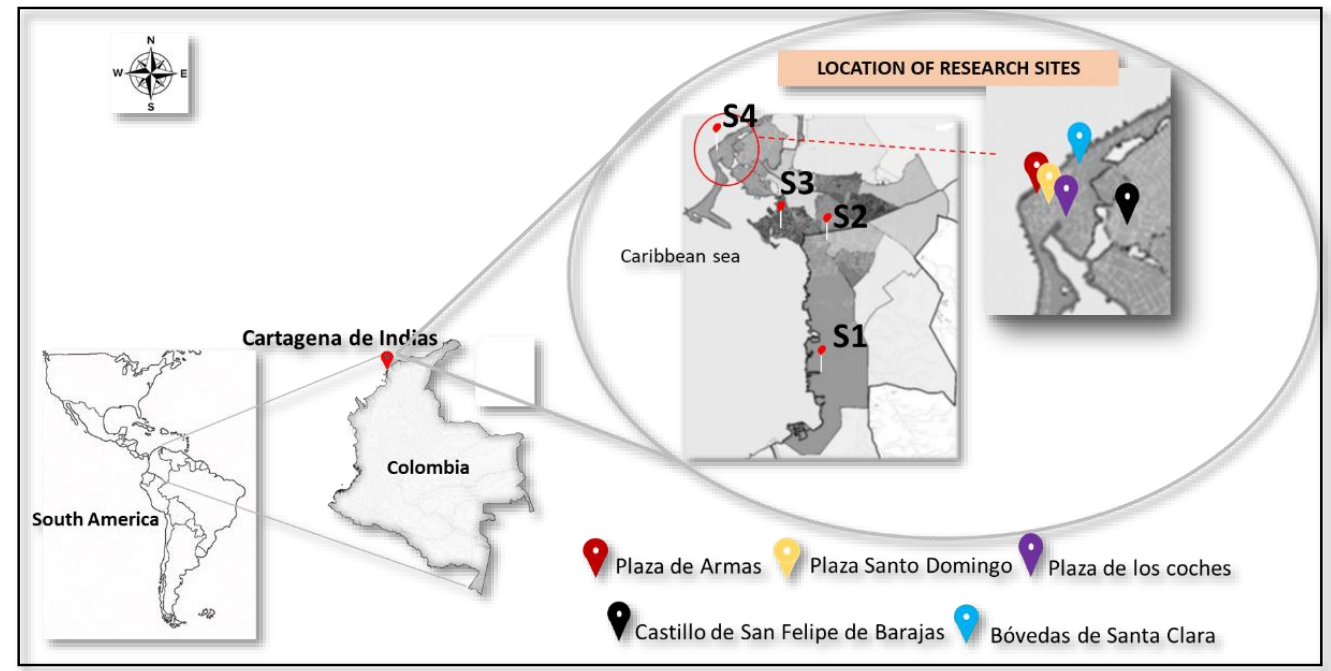

Figure 1. Map of Cartagena and the location of research sites. 
It is one of the most popular Colombian cities with rich architectural value and is a national and international tourist destination. The city was declared a Historical and Cultural Heritage of Humanity in 1984 because of its representative architectural set of the colonial period. It includes churches, streets, civil buildings, and squares that give it a unique character worldwide, making it a tourist attraction for locals and visitors.

\subsection{Meteorological and Pollutions Database}

The values of relative humidity $(\mathrm{RH} \%)$, temperature $\left(\mathrm{T},{ }^{\circ} \mathrm{C}\right)$, and precipitation $(\mathrm{P}, \mathrm{mm})$ in the city were recorded in monthly average values from the year 2008 to 2020, according to the data collected by the Centro de Investigaciones Oceanográficas e Hidrográficas in the city of Cartagena ( $\mathrm{CIOH})$ [63]. The pollution database was collected from the diagnosis environmental report [64]. In addition, in the sites of the study (S1, S2, S3, and S4, see Figure 1) pollution was measured according to the standard [65]. Figure 2 shows the behavior of relative humidity $(\mathrm{RH})$, temperature $(\mathrm{T})$, and precipitation in the period between 2008 to 2020.
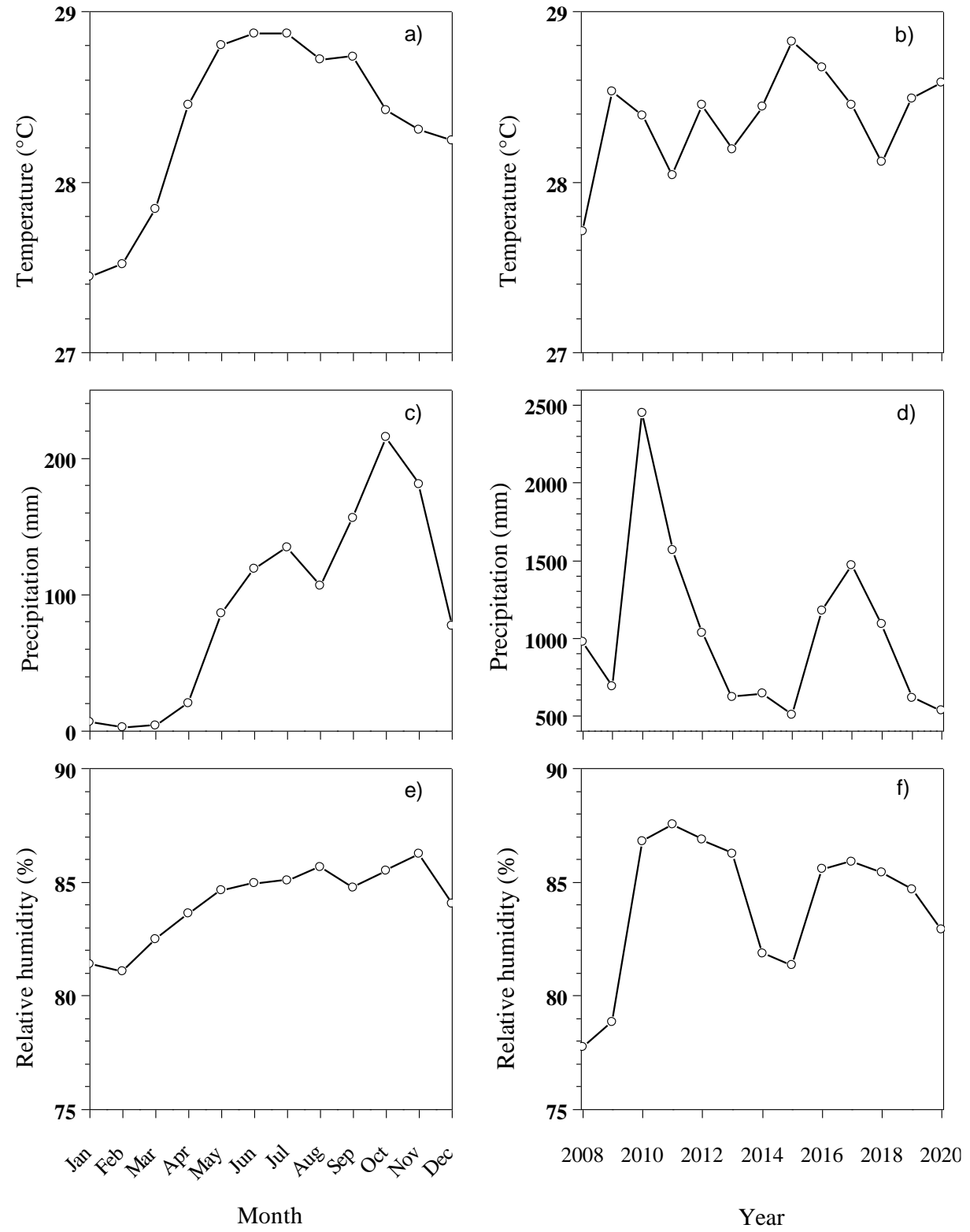

Figure 2. Meteorological parameters in Cartagena between 2008-2020. (a,b) Temperature; $(\mathbf{c}, \mathbf{d})$ precipitation; and $(\mathbf{e}, \mathbf{f})$ relative humidity. 
The average monthly temperature (Figure 2a) increases in the first semester, where the highest values are recorded in the months of June and July, followed by a decreasing trend until the month of December, which is associated with the influence of north-south displacements of the Intertropical Convergence Zone. The average annual temperature (Figure $2 \mathrm{~b}$ ) fluctuates between 27.7 and $28.8^{\circ} \mathrm{C}$. A slight increase of temperature is observed, probably due to the urban heat island effect. Figure 2c shows the average monthly precipitation. The precipitation increases during the year, with very low values in the months of January, February, and March reaching higher values in the period between May and November, with October being the month with a higher average precipitation $(215 \mathrm{~mm})$. In relation to annual average precipitation (Figure 2d), the highest precipitation is recorded between 2010 and 2011, due to the effect of the "La Niña" phenomenon [66], characterized by the considerable increase in rainfall in some areas of the country such as the Caribbean region [67]. The $\mathrm{RH}$ is observed in Figure 2e,f and the average are in a range of $78 \%$ and $88 \%$. The higher value was reported in the period 2010-2012 due to "La Niña" phenomenon. In the months of May to November, the RH was high because it is the winter period.

Levels of $\mathrm{PM}_{10}$ and $\mathrm{SO}_{2}$ near of the sites of study are observed in Table 1 . The most critical pollutant is PM10 because in some sites (see Table 1), the value is higher than the annual permissible value of $50 \mu \mathrm{m} / \mathrm{m}^{3}$ [68]. On the other hand, the $\mathrm{SO}_{2}$ observed in the Table 1 shows a higher value near at avenue Pedro de Heredia $\left(5.37 \mu \mathrm{g} / \mathrm{m}^{3}\right)$ and in industrial zone $\left(3.4 \mu \mathrm{g} / \mathrm{m}^{3}\right)$.

Table 1. Level of $\mathrm{PM}_{10}$ and $\mathrm{SO}_{2}$ reported near the sites of study.

\begin{tabular}{cccc}
\hline $\begin{array}{c}\text { Sites of the } \\
\text { Study }\end{array}$ & Data Reports [64] & $\begin{array}{c}\text { Parameters } \\
\mathbf{P M}_{\mathbf{1 0}}\left(\boldsymbol{\mu g} / \mathbf{m}^{\mathbf{3}}\right)\end{array}$ & $\begin{array}{c}\mathbf{S O}_{\mathbf{2}} \\
\left(\boldsymbol{\mu} \mathbf{g} / \mathbf{m}^{\mathbf{3}}\right)\end{array}$ \\
\hline S1 & CAI Pasacaballos & 37 & 3.4 \\
& Interception Socorro, Jardines, la Victoria & 51 & 1.27 \\
S2 & School Juan José Nieto & 33 & 1.27 \\
& Station Texaco Ternera & 24 & 5.37 \\
& School Gustavo Pulecio-Flor del Campo & 13 & 1.75 \\
& Average & 30 & 2.4 \\
& Zone Bascule Corredor de carga & 26 & 0.78 \\
S3 & CAI Bosque & 104 & 1.68 \\
& Zaragocilla & 83 & 3.02 \\
& C. San Juan de Dios & 43 & 2.54 \\
& Station of service Bazurto & 49 & 0.43 \\
& Average & 61 & 1.7 \\
S4 & CAI Lemaitre & 31 & 0.86 \\
& CAI Santa Rita & 29 & 0.87 \\
& Society Mejoras Publicas & 20 & 0 \\
& School La Candelaria & 67 & 0.4 \\
& Average & 37 & 0.5 \\
\hline
\end{tabular}

Table 2 describes the deposition rate of $\mathrm{SO}_{2}$ and $\mathrm{Cl}^{-}$in the sites of study. For the $\mathrm{SO}_{2}$, the deposition rate is higher in S3 and S4 and the classification according to ISO 9223 [23] is $\mathrm{P} 3(90<\mathrm{Pd} \leq 250)$. The chloride is higher in sites S1 and S4 with a classification ISO 9223 [23] of $S_{2}(60<S \leq 300)$ and for station $S 2$ and $S 3$ the classification is $S_{1}(3<S \leq 60)$.

Table 2. Annual deposition rate of $\mathrm{SO}_{2}, \mathrm{Cl}^{-}$in the sites of study.

\begin{tabular}{ccc}
\hline \multirow{2}{*}{ Sites of the Study } & \multicolumn{2}{c}{ Deposition Rate $\left(\mathbf{m g} / \mathbf{m}^{\mathbf{2}}\right.$.day) } \\
\cline { 2 - 3 } & $\mathbf{S O}_{\mathbf{2}}$ & $\mathbf{C l}^{-}$ \\
\hline $\mathrm{S} 1$ & 66.60 & 67.48 \\
$\mathrm{~S} 2$ & 71.78 & 44.66 \\
$\mathrm{~S} 3$ & 90.78 & 53.46 \\
$\mathrm{~S} 4$ & 87.24 & 96.27 \\
\hline
\end{tabular}




\subsection{Dose-Response Function}

In this research the degradation of materials of architectural heritage was estimated with dose-response function showed in the Equations (2)-(4) for carbon steel, copper, and zinc respectively; where Vcorr is the corrosion rate $(\mu \mathrm{m} /$ year), the pollution parameters are $\mathrm{D}_{\mathrm{SO} 2}\left(\mathrm{mg} /\left(\mathrm{m}^{2}\right.\right.$.day) and $\mathrm{D}_{\mathrm{Cl}}\left(\mathrm{mg} /\left(\mathrm{m}^{2}\right.\right.$.day $)$. The climatic parameters are temperature $\left(\mathrm{T},{ }^{\circ} \mathrm{C}\right)$, and relative humidity $(\mathrm{RH}, \%)$.

$$
\begin{gathered}
\text { Vcorr }=1.77 \mathrm{D}_{\mathrm{SO} 2}{ }^{0.52} \mathrm{e}^{[0.020 \mathrm{RH}-0.054(\mathrm{~T}-10)]}+0.102 \mathrm{D}_{\mathrm{Cl}}^{0.62} \mathrm{e}^{[0.033 \mathrm{RH}+0.040 \mathrm{~T}]} \\
\mathrm{V}_{\text {corr }}=0.0053 \mathrm{D}_{\mathrm{SO} 2}{ }^{0.26} \mathrm{e}^{[0.059 \mathrm{RH}-0.080(\mathrm{~T}-10)]}+0.0125 \mathrm{D}_{\mathrm{Cl}}^{0.27} \mathrm{e}^{[0.036 \mathrm{RH}+0.049 \mathrm{~T}]} \\
\mathrm{V}_{\text {corr }}=0.0129 \mathrm{D}_{\mathrm{SO} 2}{ }^{0.44} \mathrm{e}^{[0.046 \mathrm{RH}-0.071(\mathrm{~T}-10)]}+0.0175 \mathrm{D}_{\mathrm{Cl}}^{0.57} \mathrm{e}^{[0.008 \mathrm{RH}+0.085 \mathrm{~T}]}
\end{gathered}
$$

\subsection{Architectural Heritage as a Livelihood: Socioeconomic Characterization}

Figure 3 shows the location of the research sites for the socioeconomic characterization. Different representative sites of the city of Cartagena within the limited area of the research project: Plaza de Armas, Plaza Santo Domingo, Plaza los Coches, Castillo de San Felipe de Barajas, and las Bóvedas. Tourism in Cartagena represents one of the city's main economic activities and depends on its historical and cultural heritage. These places are the most significant in tourism and business and most popular among tourists due to their historical monuments, old buildings, luxurious restaurants, warehouses by renowned designers, and entertaining places including bars and nightclubs. Its beautiful churches and cathedrals are significant daily tourist attractions.

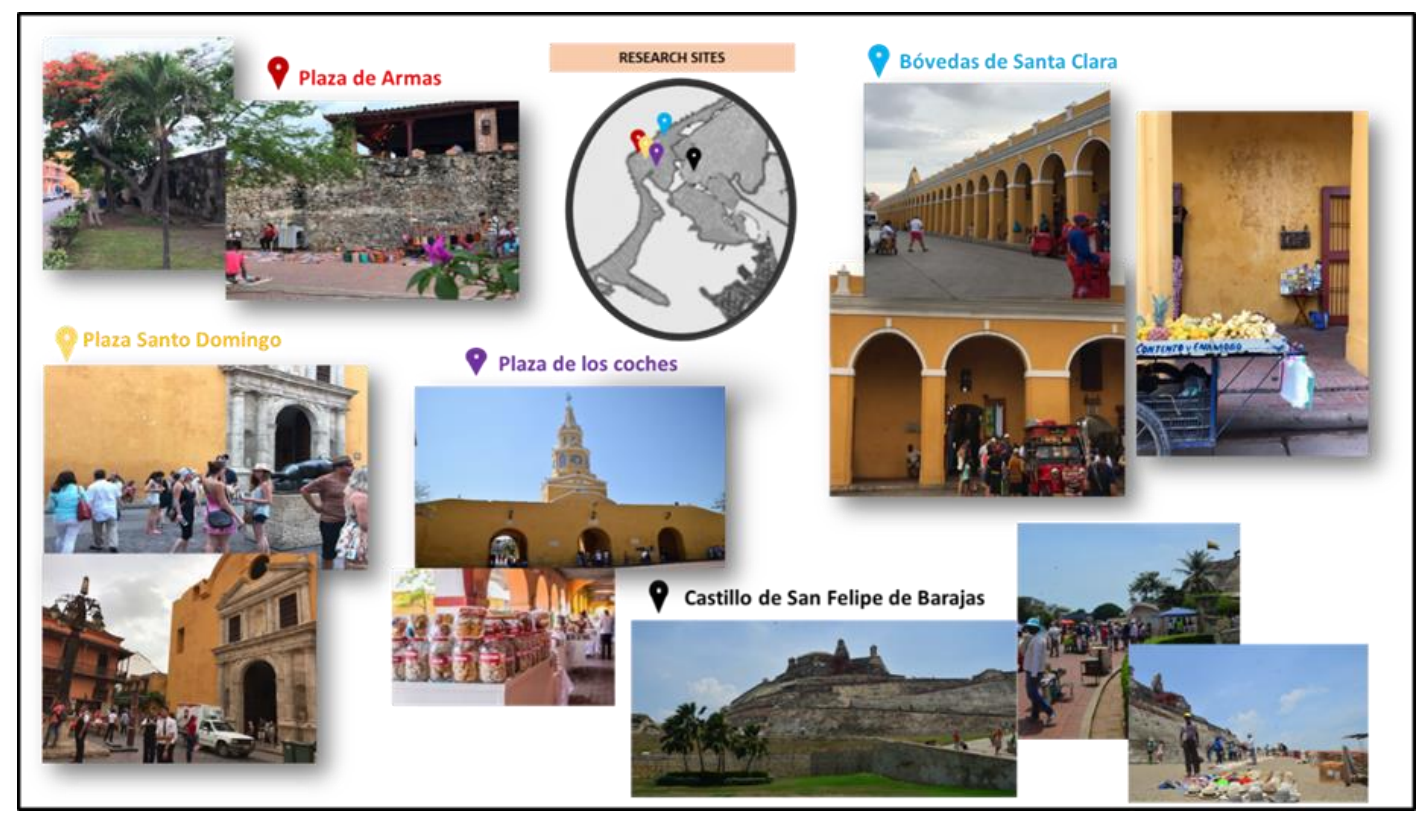

Figure 3. Delimited area of the socioeconomic characterization.

\subsubsection{Sampling and Design}

The SEIS's design complies with several factors including socio-demographic data, current housing conditions, family, education, health access, income generation, and architectural heritage. The factors studied to conduct the socioeconomic characterization of the population that derived their livelihood from the interaction of the architectural heritage as tourism were extracted from a documentary review and from previously designed tools to which adaptations were made according to research needs [69]. In order to analyze the different quantitative and qualitative conditions of the socio-economic dynamics generated in the most influential sites due to the architectural, patrimonial, and cultural content, the research was carried out, on the one hand as a basis for the detailed analysis of the literature 
on the demand of the historical zone, the perception of the homes of Cartagena de Indias and the arriving tourists [59] from which the dimensions of the perception of aspects of demand related to the economic impact. On the other hand, the factor related with the analysis of cultural heritage in a multi-attribute framework microeconomic perspectives [70]. Participants are economically active, employed, or independent workers, and their main source of income is tourism. Sample size is 174 people from different economic activities of the sector. This sample is taken from the total population with a confidence ratio of $95 \%$. The interviews were conducted in October 2016 across a descriptive study based on a structured questionnaire. The instrument contained 65 items that were grouped in 6 dimensions: (1) housing, (2) family, (3) education, (4) social security, (5) income generation, and (6) architectural heritage. The aim was to characterize the population's conditions in social and economic aspects. The information was obtained through an interview of approximately $25 \mathrm{~min}$ long. People gave their consent in which they were explicitly indicated that aggregate use of the data would be used exclusively for research purposes. The interviewers were students from the industrial engineering program at Antonio Nariño University who received $20 \mathrm{~h}$ of intensive training to apply the SEIS.

\subsubsection{Variables and Measures}

The details of the factors analyzed in this investigation are as follows:

\section{- Demographics factors}

The age variable was introduced in the research to classify socioeconomic information by groups from younger to older, dividing them into five groups (15-26, 27-39, 40-51, 52-64, and 65+) for statistical analysis. Gender is considered for the distribution of the population pyramid with the age variable. Other variables recognize the group as special or vulnerable groups, including Indigenous, Raizal or islander, Gypsy, Mulatto, Palenquero, or Afro-Colombians. Several variables even included the marital status, indicating married or not married, common-law marriage, separated, widowed, and unmarried.

\section{- Dwelling factors}

Housing refers to the physical place where the interviewees live. These variables are dichotomous between houses and apartments. As Tupėnaite, Naimavičienė, Bagdonavičius, and Sabaliauskas [71] mention in their report, the housing tenure is an owner-occupied home without any outstanding loans or mortgages or living in rented dwellings. The housing quality relates to the construction materials for wall, floor, ceiling, and furnishings. It also includes information on the number of rooms available and their socioeconomic level. Housing in Cartagena de Indias might be categorized as being low level (1-2), middle level (3-4), or upper level (5).

\section{- Family factors}

Some determining factors are the sizes of families, the number of people in the family within the dwelling, and kinship with the head of household. It also includes the identification of any family member belonging to the LGBTQ community.

- Education factors

The levels of education had the following variables: illiterate, primary, intermediate, or more according to the years of education.

\section{- Health factors}

Social security coverage gets classified into three categories among private, public, and no coverage. It also considers people with physical and mental limitations.

\section{- Household income factors}

Household income is the combined income of all people in the household. Variables like economic activity, work formality, job location, time and training in the trade, the sale of souvenirs, trade association, language proficiency, primary clients, generated jobs, economic dependence, family economy, and savings culture were analyzed. 


\section{- Architectural heritage factors}

This variable included the state of degradation, responsibility for monuments conservation, condition of architectural monuments, and impact of the economy and heritage conservation proposal.

\subsubsection{Characteristics of the Population}

Figure 4 shows the characteristics of the population pyramid. It indicates that of the 174 people included in the sample, half were male, and the highest representation was from the age group between 15-26 (26.79\%). The population distribution related to gender shows that $36 \%$ were females and $64 \%$ were males.

\section{Gender}

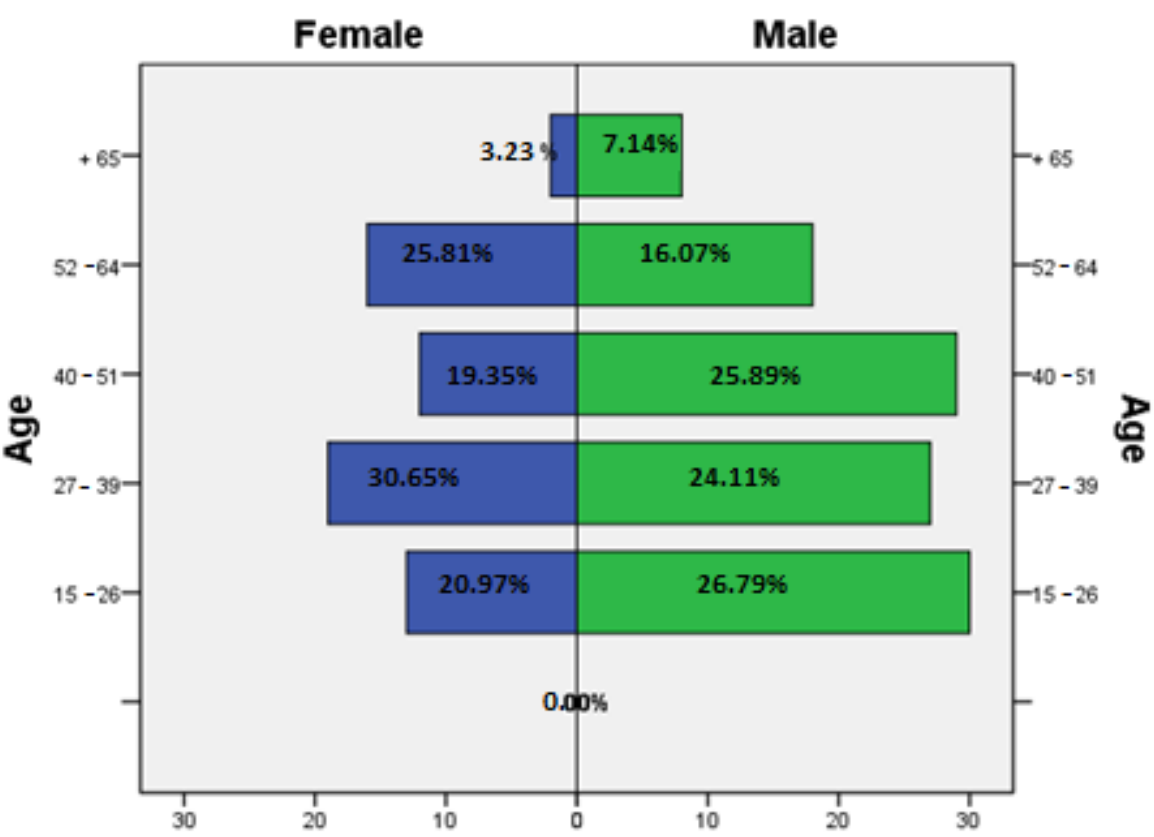

Figure 4. Population pyramid according to the age group of the 174 people included in the sample: SEIS, 2016.

Table 3 shows the characteristics of the population by gender and age group. According to the demographic factors, approximately $12.6 \%$ of the sample was composed by afro-descendants, and $10.9 \%$ was by indigenous people.

Among all the ethnic groups included, $71.3 \%$ of the population did not include vulnerable groups. The marital status also estimated that the highest proportion of the people were in common-law marriage (42\%), with a significant gender differential (29\% among male and 13\% among female). According to the housing type, the youngest age group (15-26 years) lived at home while the age ranging 27-39 years old commonly lived in apartments. The resident distribution sector changed by age, so the youngest individuals were highly concentrated in the tourism sector compared to the oldest age group (15-26). The ages ranging between 27-39 and 40-51 lived in a residential sector of the city. It implied that $94 \%$ of the sample used their home as a dwelling place, and the other $6 \%$ used their housing for productive businesses. The age group 40-51 (12\%) has a similar tendency to live in rental homes, while the youngest age group (12.9\%) lived in owner-occupied homes. Furthermore, $94 \%$ of the sample had quality services, and their homes were constructed of masonry materials. The houses, especially from the group aged 27 to 39 , had more than two rooms. In addition, $83.9 \%$ of the population belonged to the lower socioeconomic level, where the difference for both genders had approximately $20 \%$ of the men $(53.3 \%)$ above the women (31.6\%). The percentage of subjects belonging to the lower, middle, or upper classes also decreased slightly from age $27-39(23.6 \%)$ to age 65 or older $(4 \%)$. 
Table 3. Characteristics of the population by gender and age groups: SEIS, 2017.

\begin{tabular}{|c|c|c|c|c|c|c|c|c|}
\hline \multirow{2}{*}{ Factors } & \multirow{2}{*}{$\begin{array}{c}\text { All } \\
\text { Sample }\end{array}$} & \multicolumn{2}{|c|}{ Gender } & \multicolumn{5}{|c|}{ Age Group } \\
\hline & & Male & Female & $15-26$ & $27-39$ & $40-51$ & $52-64$ & $65+$ \\
\hline No. (\%) & $174(100)$ & $112(64)$ & $62(36)$ & $43(24.7)$ & $46(26.4)$ & $41(23.6)$ & 34 (19.5) & $10(5.7)$ \\
\hline \multicolumn{9}{|l|}{ Demography } \\
\hline \multicolumn{9}{|l|}{ Ethnic group (\%) } \\
\hline Indigenous & 10.9 & 8.6 & 2.3 & 1.7 & 5.7 & 3.4 & & \\
\hline Raizal/Islander & 2.3 & 2.3 & & 1.1 & & 1.1 & & \\
\hline Mulatto & 1.7 & 0 & 1.1 & & 1.7 & & & \\
\hline Palenquero & 1.1 & 1.1 & & 0.6 & & & 0.6 & \\
\hline Afro-descendants & 12.6 & 7.5 & 5.2 & 1.7 & 2.9 & 1.1 & 4.6 & 2.3 \\
\hline None of them & 71.3 & 44.3 & 27 & 19.5 & 16.1 & 17.8 & 14.4 & 14.4 \\
\hline \multicolumn{9}{|l|}{ Status Marital } \\
\hline Married & 15 & 9.8 & 5.2 & & 3.4 & 3.4 & 6.5 & 1.7 \\
\hline Not married & 85. & 54.7 & 30.3 & 24.7 & 23 & 20.0 & 13.3 & 4.0 \\
\hline \multicolumn{9}{|l|}{ Dwelling } \\
\hline house & 65.0 & 41.4 & 23.6 & 17.8 & 13.2 & 15.5 & 14.4 & 4.0 \\
\hline Apartment & 35.0 & 23 & 7.5 & 6.9 & 13.2 & 8.0 & 5.2 & 1.7 \\
\hline \multicolumn{9}{|l|}{ Status tenure } \\
\hline $\begin{array}{c}\text { Owner-occupied } \\
\text { home/outstanding loan }\end{array}$ & 46.0 & 30.5 & 15.5 & 12.6 & 6.9 & 10.3 & 11.5 & 4.6 \\
\hline $\begin{array}{l}\text { Owner-occupied home/without } \\
\text { outstanding loan }\end{array}$ & 2.9 & 1.7 & 1.1 & 1.1 & 0.6 & 1.1 & & \\
\hline Rent home & 51.2 & 32.2 & 18.9 & 10.9 & 19 & 12.1 & 8.1 & 1.2 \\
\hline \multicolumn{9}{|l|}{ Housing quality (\%) } \\
\hline Public services & 94.3 & 59.8 & 34.5 & 24.1 & 24.7 & 20.7 & 19.0 & 5.7 \\
\hline Construction materials & 94.3 & 59.2 & 35.1 & 24.1 & 24.7 & 20.7 & 19.0 & 5.7 \\
\hline Rooms available $\leq 2$ & 87.4 & 56.9 & 30.5 & 22.4 & 23.0 & 20.1 & 16.6 & 5.1 \\
\hline \multicolumn{9}{|l|}{ Socio-economic status (\%) } \\
\hline Upper class $(\geq 5)$ & 1.7 & 1.7 & & & 0.6 & 0.6 & & 0.6 \\
\hline Middle class (4-3) & 14.3 & 10.3 & 4.0 & 5.2 & 2.3 & 2.3 & 3.5 & 1.2 \\
\hline Lower class (2-1) & 83.9 & 53.3 & 31.6 & 19.6 & 23.6 & 20.7 & 16.1 & 4.0 \\
\hline \multicolumn{9}{|l|}{ Family } \\
\hline \multicolumn{9}{|l|}{ Number of households (\%) } \\
\hline 1 & 71.2 & 43.1 & 28.1 & 17.3 & 18.4 & 17.8 & 13.2 & 4.6 \\
\hline$\geq 1$ & 28.8 & 21.3 & 7.5 & 7.4 & 8 & 5.8 & 6.3 & 1.1 \\
\hline \multicolumn{9}{|l|}{ Number of people (\%) } \\
\hline 4 & 52.8 & 29.9 & 22.9 & 10.3 & 13.2 & 13.2 & 12.6 & 3.6 \\
\hline$\geq 4$ & 47.2 & 17.3 & 29.9 & 14.4 & 13.2 & 10.4 & 6.9 & 6.4 \\
\hline LGBTI & 1.7 & & 1.7 & 1.7 & & & & \\
\hline \multicolumn{9}{|l|}{ Education } \\
\hline Illiterate/informal & 0.6 & & 0.6 & & & & 0.6 & \\
\hline Primary & 27.0 & 18.4 & 8.6 & 3.4 & 6.3 & 7.5 & 6.3 & 3.4 \\
\hline Intermediate or more & 72.4 & 46 & 26.4 & 21.3 & 20.1 & 16.1 & 12.6 & 2.3 \\
\hline \multicolumn{9}{|l|}{ Health } \\
\hline \multicolumn{9}{|l|}{ Coverage $(\%)$} \\
\hline Private & 19.5 & 13.8 & 5.7 & 4.6 & 3.4 & 2.9 & 6.3 & 2.3 \\
\hline Public & 68.4 & 40.8 & 27.6 & 15.5 & 20.1 & 17.3 & 12.1 & 3.4 \\
\hline No coverage & 21.3 & 16.7 & 4.6 & 5.2 & 5.2 & 6.3 & 4.5 & \\
\hline Limited capacity & 9.2 & 6.9 & 2.3 & 0.6 & 2.3 & 2.9 & 3.4 & \\
\hline
\end{tabular}

Family distribution differentiates according to age. The younger individuals lived in one dwelling as compared to the age group of above 65 . However, the family's size was homogeneous where $52.8 \%$ of the sample had four members and $47 \%$ had more than four members. This proportion increased with age but it is similar to gender. Furthermore, $1.7 \%$ of the sample population belonging to the LGBTI community was female. Of the sample, $72 \%$ had intermediate education or more, with separate results between genders ( $46 \%$ among males vs. $26.4 \%$ among females). Of the sample, $88 \%$ had health insurance, out of which $19 \%$ was private, and $68 \%$ was public, and $9.2 \%$ of them had mental or physical 
disabilities. This value increases with age and range by gender $(6.9 \%$ among males vs. $2.3 \%$ among females).

\subsubsection{Statistical Analysis}

All variables used descriptive frequencies as primary sample units that serve as the first reference frame of this baseline. These analyses use SPSS version 23. Bivariate analyses were performed between the exposure variables with the variables of age and gender. It establishes the tendency of the population surveyed in social and economic terms in comparison to the activities they develop around monuments with historical and cultural value.

\section{Results}

\subsection{Estimation of the Deterioration of Materials}

Table 4 show the annual material deterioration estimated with a dose-response function. The corrosion rate for carbon steel, copper and zinc were calculated using the Equations (2)-(4). In general, the atmospheric corrosion of the sites S1 and S4 are categorized as very high for all materials studied, corresponding to $80<$ Vcorr $<200 \mu \mathrm{m} /$ year for carbon steels; $2.8<$ Vcorr $<5.6 \mu \mathrm{m}$ /year for copper, and $4.2<$ Vcorr $<8.4 \mu \mathrm{m} /$ year for zinc, after the first year of exposure. The stations S2 and S3 are categorized as high, with corrosion rate of $50<$ Vcorr $<80 \mu \mathrm{m}$ /year para el carbon steel; $1.3<$ Vcorr $<2.8 \mu \mathrm{m} /$ year for copper and $2.1<$ Vcorr $<4.2 \mu \mathrm{m} /$ year for zinc.

Table 4. Annual material deterioration estimated.

\begin{tabular}{cccc}
\hline \multirow{2}{*}{ Sites of the Study } & \multicolumn{2}{c}{ Corrosion Rate $(\mu \mathrm{m} /$ Year $)$} & Zinc \\
\cline { 2 - 4 } & Carbon Steel & Copper & 5.38 \\
S1 & 102.49 & 3.26 & 4.51 \\
S2 & 87.67 & 2.98 & 5.0 \\
S3 & 98.41 & 3.13 & 6.48 \\
S4 & 124.74 & 3.57 & 1.1 \\
Level acceptable & 20 & 0.8 & $3.55^{2}$ \\
Report Data & $26.5^{2}$ & $1.19^{3}$ & \\
\hline
\end{tabular}
${ }^{1}[72]^{2}[73]^{3}[74]$.

\subsection{Socioeconomic Characterization}

3.2.1. Socioeconomic Incomes vs. Physical State of Architectural Heritage

Table 5 identifies the percentage of variables as household incomes include the influence of architectural heritage and the perception on the monuments' physical state.

The primary variable of the main economic activities of the population is trading (50\%) which is prevalent between the ages $27-39$ and $40-51$ (14.9\% and 13.2\%, respectively). After this, it appears tourism (36\%) and services (13\%) involved the youngest age group (15-26) but decreased from 6.3 to $0.6 \%$ among ages $52-64$. Furthermore, $87 \%$ of those activities are informal labor as $49 \%$ of the sample are business owners located in the parks and squares in public spaces. The ages 27-39 were dominant in these sites, followed by the ages 52-64 due to the largest tourist visits. Additionally, $40 \%$ of the items sold were handicrafts as they are significant sources for the tourists who appreciate the cultural expressions of the architectural heritage with various objects. These articles were sold more by the age group from 52 to 64 , followed by the ages 27 to 39. The language was also determined, where $38 \%$ of the subjects speak English, Portuguese, and French. This is more common among the younger age groups. The population sample sold their products to national tourists (56\%), foreign tourists (35\%), and only 8.6\% were local customers. Finally, the years of experience that the respondent, who remained in the surroundings of the architectural patrimonies, which is reflected in the population with a permanence of more than 10 years (48\%), 16.1\% belonging to the ages between 40-51, followed by the ages 52-64 (16.1\%). Furthermore, $72 \%$ of the subjects stated that the patrimonial monuments degraded due to environmental 
conditions, but they did not have a maintenance plan to protect them against it. In total, $63 \%$ of the sample stated that the responsibility for conservation lies with the government. The proportion between the ages $40-51$ increasingly held citizens responsible for heritage conservation. There is also a significant proportion $(51 \%)$ of the subjects, mostly males $(35 \%)$ instead of females $(16 \%)$, whose income would be affected by the degradation of the architectural heritage because they could disappear along with the area's tourism. The proportion of conservation availability varies with age, where the younger individuals contribute more than the older age group (65+ years). The segment with the protection measures increased with gender while age differentials decreased significantly. This also includes the area's security, social control, and condemning were the measures proposed by the subjects.

Table 5. The baseline of the population's economic study by gender and age group: SEIS, 2017.

\begin{tabular}{|c|c|c|c|c|c|c|c|c|}
\hline \multirow{2}{*}{ Characteristics } & \multirow{2}{*}{$\begin{array}{c}\text { All } \\
\text { Sample }\end{array}$} & \multicolumn{2}{|c|}{ Gender } & \multicolumn{5}{|c|}{ Age Group } \\
\hline & & Male & Female & $15-26$ & 27-39 & $40-51$ & $52-64$ & $65+$ \\
\hline No. $(\%)$ & $174(100)$ & $112(64)$ & $62(36)$ & $43(24.7)$ & $46(26.4)$ & $41(23.6)$ & $34(19.5)$ & $10(5.7)$ \\
\hline \multicolumn{9}{|l|}{ Household incomes factors (\%) } \\
\hline Main economic activities & 98.8 & & & & & & & \\
\hline Trade & 50.0 & 31.6 & 18.4 & 7.5 & 14.9 & 13.2 & 11.5 & 2.9 \\
\hline Tourism & 36.2 & 23.0 & 13.2 & 10.9 & 9.2 & 6.3 & 6.9 & 2.9 \\
\hline Services & 12.6 & 9.2 & 3.4 & 6.3 & 2.3 & 3.4 & 0.6 & \\
\hline Workplace & 98.4 & & & & & & & \\
\hline Historic Center & 18.4 & 13.2 & 5.2 & 7.5 & 5.2 & 4.0 & 1.7 & \\
\hline San Felipe Castle & 23.6 & 20.1 & 3.4 & 3.4 & 3.4 & 8.2 & 6.3 & 2.3 \\
\hline Parks and squares & 48.9 & 25.3 & 23.6 & 10.9 & 13.9 & 10.3 & 11.5 & 2.3 \\
\hline Monuments & 7.5 & 4.0 & 3.4 & 2.4 & 3.4 & 0.6 & & 1.1 \\
\hline \multicolumn{9}{|l|}{ Labor } \\
\hline Formal & 12.6 & 9.2 & 3.4 & 5.7 & 1.7 & 2.9 & 1.1 & 1.1 \\
\hline Informal & 87.4 & 55.2 & 32.2 & 19.0 & 24.7 & 20.7 & 18.4 & 4.6 \\
\hline Language & 38.5 & 27.6 & 10.9 & 9.7 & 9.2 & 8.1 & 8.1 & 2.8 \\
\hline \multicolumn{9}{|l|}{ Main customer } \\
\hline Local tourism & 8.6 & 5.1 & 3.4 & 2.3 & 1.7 & 2.3 & 1.7 & 0.6 \\
\hline National tourism & 56.3 & 38.5 & 17.8 & 12.6 & 16.1 & 14.4 & 9.2 & 4.0 \\
\hline Foreign tourism & 35.1 & 20.7 & 14.4 & 9.8 & 8.6 & 6.9 & 8.6 & 1.1 \\
\hline \multicolumn{9}{|l|}{ Time worked } \\
\hline$<1$ year & 12.6 & 5.2 & 7.5 & 8 & 2.9 & 0.6 & 1.1 & \\
\hline $1-5$ years & 21.8 & 12.6 & 9.2 & 9.2 & 8 & 2.3 & 1.7 & 0.6 \\
\hline $5-10$ years & 16.7 & 9.8 & 6.9 & 4 & 5.7 & 4.6 & 2.3 & \\
\hline$>10$ years & 48.8 & 36.7 & 12.1 & 3.4 & 9.8 & 16.1 & 14.4 & 5.1 \\
\hline \multicolumn{9}{|l|}{ Income } \\
\hline$<\mathrm{US} 220$ & 32.8 & 17.2 & 15.6 & 8.6 & 11.5 & 5.3 & 6.3 & 1.1 \\
\hline US220-US660 & 66.1 & 45.5 & 20.6 & 16.0 & 14.9 & 17.2 & 13.2 & 4.6 \\
\hline$>660$ & 1.1 & 1.1 & & 0.6 & & 0.5 & & \\
\hline \multicolumn{9}{|l|}{ Heritage monuments factors } \\
\hline Degradation & 72.4 & 46.6 & 25.9 & 13.8 & 22.4 & 19.0 & 13.2 & 4.0 \\
\hline Good conditions & 26.4 & 17.2 & 9.2 & 10.4 & 4.0 & 4.0 & 6.3 & 1.7 \\
\hline \multicolumn{9}{|l|}{ Responsibility for conservation } \\
\hline Government & 63,2 & 39.1 & 24.1 & 14.9 & 12.1 & 18.4 & 12.6 & 5.2 \\
\hline Private enterprises & 8.0 & 6.3 & 1.7 & 1.1 & 1.1 & 1.7 & 4 & \\
\hline Citizens & 27 & 17.8 & 9.2 & 24.7 & 26.4 & 23.6 & 19.5 & 5.7 \\
\hline Income allocated & 50.6 & 34.5 & 16.1 & 13.2 & 10.3 & 12.6 & 12.1 & 2.3 \\
\hline Conservation Availability & 92.0 & 59.2 & 32.8 & 22.4 & 24.7 & 20.7 & 18.4 & 5.7 \\
\hline Protection measures & 98.0 & 62.4 & 35.6 & 24.7 & 26.4 & 23.0 & 18.9 & 5.0 \\
\hline
\end{tabular}

\subsubsection{Bivariate Correlation Analysis}

The bivariate correlation, according to economic and architectural heritage factors, is presented in Table 6. The negative incidence of some economic factors is also observed 
(income, type of work, workplace, main economic activities, time worked). The negative value shows that the state of heritage has a negative incidence in the economy, especially in the cultural tourism. Furthermore, the heritage factors (state of heritage monuments, income impact, protection measure) evidence a negative value. This generates high incidence in the economic factors, producing a possible effect in the sustainability, especially in the income. The higher negative values $(-0.167,-0.185$, and -0.184$)$ show that the type of work and main economic activities exceed the normal value (0.05), indicating a possible alarm over sustainability of the heritage.

Table 6. Pearson's Correlation results according to economic and architectural heritage factors. SEIS, 2016.

\begin{tabular}{|c|c|c|c|c|c|}
\hline & & \multicolumn{4}{|c|}{ Heritage Factors } \\
\hline & & $\begin{array}{l}\text { State of Heritage } \\
\text { Monuments }\end{array}$ & Income Impact & $\begin{array}{l}\text { Economic } \\
\text { Impact }\end{array}$ & $\begin{array}{c}\text { Protection } \\
\text { Measure }\end{array}$ \\
\hline \multirow{6}{*}{$\begin{array}{l}\text { Economic } \\
\text { factors }\end{array}$} & Income & -0.029 & -0.047 & 0.034 & -0.038 \\
\hline & Type of work & -0.167 * & 0.030 & 0.135 & 0.035 \\
\hline & Work place & -0.119 & 0.123 & 0.002 & 0.025 \\
\hline & $\begin{array}{l}\text { Main economic } \\
\text { activities }\end{array}$ & -0.057 & -0.034 & $-0.184 *$ & $-0.185^{*}$ \\
\hline & Main customers & 0.069 & $0.189 *$ & 0.109 & \\
\hline & Time worked & $-0.160 *$ & -0.020 & -0.108 & \\
\hline
\end{tabular}

* The correlation is significant at the 0.05 level (bilateral).

The adverse incidence of degradation of architectural heritage remaining on type of work was $0.167(p<0.05)$. The responsibility for architectural heritage conservation had a heavy negative incidence on household income. The protective measures for area security, social control, or denouncement negatively affected the modality of work and the sold products. The continued deterioration of architectural heritage could affect the income so adversely that its main clients (tourists) stop visiting these monuments.

\section{Discussion}

\subsection{Influence of Pollution and Climate in the Deterioration of Architectural Materials}

Atmospheric corrosion is a natural phenomenon that causes damages or destruction in the materials due to reaction with the pollutants $\left(\mathrm{SO}_{2}, \mathrm{Cl}^{-}, \mathrm{NOx}, \mathrm{O}_{3}\right.$, etc. $)$ and climate parameters ( $\mathrm{T}, \mathrm{RH}$, precipitations, and winds). In the case of Cartagena de Indias, the concentration of $\mathrm{SO}_{2}$ in the different research sites originated due to use of fossil fuels with high level of sulphur [75]. It is observed that the high value (see Table 1) is present near avenues or streets with heavy traffic. It is highlighted that motorized vehicles are a source of harmful pollutants (NOX, $\mathrm{SO}_{2}$ and PM) [76] and in 2020 the 56\% of vehicles were motorized [77]. The classification as P3 is considered extreme due to accelerator effect in the corrosion process of metallic materials and limestones, generating reactions that produce dissolved acids. Results by Oliveira et al. [9] establishes that vehicular traffic near The Walled City of Cartagena de Indias probably damages the surface of the building materials.

In the marine environment, the chloride ion is another accelerator factor of corrosion and degradation of materials [78]. The chloride ion accelerated the corrosion when metal surface was wet. Ambler and Bain [79] said that a $\mathrm{RH}$ of $78 \%$ in equilibrium with a saturated solution of $\mathrm{NaCl}$ generated a strong acceleration of corrosion of carbon steel. In this case, the values reported for $\mathrm{RH}$ in the Figure $3 \mathrm{e}, \mathrm{f}$ are higher than cited by Ambler and Bain. It is well-known that the salinity in the marine atmospheres changes according to the winds (directions and velocity), distance from the coast, topographic, altitude, among others [80]. These factors have a strong influence in the deterioration of materials due to the salts, acid gases, particles, and carbonation and sulfation reactions contribute to the formation of crusts [18]. The results observed in the Table 3 show high deterioration degree for these materials, generated by high level of pollutants $\left(\mathrm{SO}_{2}, \mathrm{Cl}^{-}\right)$and climate conditions; it is observed that sites of study are located near the sea and the industrial zone. These results compared with the tolerable corrosion rate reported by [24] are extremely high; for example, for cooper monument it is $1.0 \mu \mathrm{m}$ /year and for zinc is $1.6 \mu \mathrm{m}$ /year, with tolerable time 
between maintenance of 50 years. In another study, it is shown that the corrosion rate of copper is $0.8 \mu \mathrm{m}$, for carbon steel $20 \mu \mathrm{m}$, and for zinc $1.1 \mu \mathrm{m}$, exceeding in all cases the maximum level recommended for 2020 [33].

According to the results obtained $[9,81,82]$, contaminants, salts, moisture, and poor drainage maintenance trigger the deterioration of the material alongside the absence of public institutions dedicated to its preservation. For future scenarios in Cartagena de Indias, it is advisable the installation and/or updating of Meteorological Data Acquisition System and pollution, since both parameters have influence in the materials degradation [24] affecting the Outstanding Universal Value (OUV) of World Heritage properties [83]. It is important to know the sites in Cartagena de Indias that need special attention as a result of being in areas where anthropogenic activity is relevant, such as S1 and S4, located in the industrial zone and the historical center respectively. The preservation of historical heritage is important as it has a cultural, economic, and developmental impact on the city.

\subsection{Sustainability of Architectural Heritage}

Historical centers like the one in Cartagena de Indias have a close connection with national citizens and foreigners. Tourism in historical cities may contribute to economic growth and generation of employment, as Timothy [45] states in his research. This improves the social development (quality of life) of the population dedicated to several activities such as tourism, services, and trade [6]. The cultural tourism makes notable contributions to the economic dynamics of the city and helps develop the tourism and leisure industry. The results show that the socio-economic development of the architectural heritage is inadequate since $48 \%$ of the sample interviewed had established their informal businesses for more than 10 years (see Table 5) for two reasons. First, the lack of institutional offers for the formalization of jobs and businesses in this sector, and second the measures restricting the development of those activities in streets that affect direct businesses that pay the taxes in compensation for the valuation and conservation of heritage. According to the study results, the interviewees argue that the lack of culture and citizen awareness in the community generates a negative impact on the area's economy. Artal-tur et al. [40] report that the characteristics (level of studies, income, gender, young people, etc.) of the visitor are important to increase the level of economic sustainability.

The correlation results (see Table 6) show that tourist visits decrease with the increase in deterioration of the architectural heritage. The economic impact generated by the heritage deterioration establishes a negative correlation with the main economic activities of the sector including commerce, hotels, guest houses, and restaurants. The tourism in the region depends mostly on the quality of heritage sites and availability of them [84]. Economic assessment of business benefits from the heritage is so significant that it is impossible to urge direct and indirect goods and services if it is non-existent on the site [85]. The formal jobs might be more affected, according to the results [60], whereas the informal jobs will only shift from one place to another. McLoughlin, Kaminski, and Sodagar [85] establish that the increased business benefits from heritage may include more tourists, a higher hotel occupancy rates, restaurant demand and public transport, and increase of sales of traditional craft that reflect the culture. In other words, increase of culture tourism recognized by four elements as tourism, cultural assets, the consumption and the tourist [41]. There is a negative correlation of protection measures for architectural heritage with economic activities, restricting land usage. It implies that informal businesses cannot be inactive, and they should promote association to formalize its businesses within the city's historical center. It would instead limit the developing activities that are incompatible with land usage. It would also endanger heritage conservation, like horse-drawn cars, discotheques, bars, and those informal sales people invading the public space. They might be a potential business for local's economic development but unsustainable for architectural heritage $[53,86]$.

There are also positive factors related to socio-economic development from the architectural heritage, like the restoration of historical buildings and their provision of services 
promotes compatibility and sustainability in the long term. The participation of residents in the use of heritage to adopt and implement the Master Plan for Heritage Management and Protection would attract more tourism and produce more complementary goods and services. The public participation and cooperation among stakeholders reflects the positive impact in the conservation processes [87]. The latter will be possible according to the procedure of several economic activities and the responsibility of the heritage conservation. According to the study conducted by Yung et al. [88], heritage conservation is essential for both the historic buildings and the sustainable development of the regions.

According to the results obtained (see Table 6), the economic impacts of cultural tourism show that the $66.6 \%$ of interviewees have an income between US 220-US 660 . Grazuleviciute and Urbonas [89] say that the influence of the architectural heritage and household income are beneficial due to increase of visitors, the creation of additional household income, and an improvement in the quality of life of the local population. In general, economic impacts of cultural tourism are direct, (individual benefits by selling products), indirect (are benefits obtained by other tourism holders), and induced (result of direct and indirect effects) [90].

\section{Conclusions}

This study highlights the impact of environmental pollution in the sustainability of architectural heritage in Cartagena de Indias, Colombia. The potential risk of deterioration of architectural heritage of the city deriving from air pollution and climate changes are high, with estimating corrosion rate (Vcorr) between $80<$ Vcorr $<200 \mu \mathrm{m} /$ year for carbon steels; $2.8<$ V corr $<5.6 \mu \mathrm{m} /$ year for copper and $4.2<\mathrm{V}$ corr $<8.4 \mu \mathrm{m} /$ year for zinc. The contaminants $\left(\mathrm{Cl}^{-}\right.$and $\left.\mathrm{SO}_{2}\right)$ are an important factor in the corrosion process, as well as $\mathrm{RH}$ and temperature. The results can serve to prompt additional studies and highlight the need of public policies for air pollution reduction in Cartagena de Indias, especially in the historic center to prevent further damage.

Regarding sustainability of architectural heritage, also in this paper the relevant risks between economic aspects and heritage degradation with indicators of socioeconomic impact were determined. The economic impacts generated by the heritage deterioration establish a negative correlation; it is possible that this result is originated due to the lack of culture and citizens' awareness. The economic factor of the population has been influenced by the employment generated in its historical areas. This is exclusively due to the attractive history and culture of the architectural heritage of Cartagena de Indias for locals and visitors. The value of the architectural heritage perceived by the interviewees is low because of the area's structural problems including the lack of institutional supply, the invasion of the public space, economic activities incompatible with land usage, and tourists and locals' attitude towards the protection and conservation of heritage. Investment is also insufficient for the development and renovation of the buildings and/or potential monuments of the historic center to attract visitors and increase other tourism benefits. Despite the efforts to manage the conservation and maintenance of the architectural heritage, in some cases, the market supply and demand mechanisms allow the private sector investment; However, more government involvement is required for increased social value. Promoting incentives, e.g., real estate sectors, also strengthens the process and ensures sustainability over time.

Finally, it is important to reinforce the quality education of future generations to develop entrepreneurial skills and innovation in those who feel attracted to the dynamics of tourism from the architectural heritage. The creation of tourism workers' associations in the historical area would be possible by adopting inclusive public policies, concentrating efforts in the economic development, to optimize investment in the conservation, maintenance, and administration of the historical and cultural heritage. This will improve the quality of life for these individuals as they meet their basic social and economic needs.

Author Contributions: Conceptualization, L.D.L.H.V. and M.B.B.; methodology, H.C., W.B.H. and L.A.G.; software, validation, and formal analysis, W.B.H.; investigation, H.C. and J.F.R.-R.; writingoriginal draft preparation, H.C., W.B.H. and J.F.R.-R.; writing-review and editing, H.C., J.H.-F. and 
J.F.R.-R.; supervision, H.C.; project administration, J.F.R.-R. and H.C.; funding acquisition, H.C. All authors have read and agreed to the published version of the manuscript.

Funding: This research was funded by Universidad Antonio Nariño, grant number 2015032.

Institutional Review Board Statement: The study was conducted according to the guidelines of the Declaration of Helsinki and approved by Ethics Committee of University Antonio Nariño (ordinary session and date of approval 19 May 2015).

Informed Consent Statement: Informed consent was obtained from all subjects involved in the study.

Data Availability Statement: Data is contained within the article.

Acknowledgments: The authors would like to thank the Institucion Tecnologica Colegio Mayor de Bolívar, Universidad Tecnologica de Bolivar and Cotecmar for their operational support during the execution.

Conflicts of Interest: The authors declare no conflict of interest.

\section{References}

1. Yuan, M.; Yin, C.; Sun, Y.; Chen, W. Examining the associations between urban built environment and noise pollution in high-density high-rise urban areas: A case study in Wuhan, China. Sustain. Cities Soc. 2019, 50, 101678. [CrossRef]

2. Morano, P.; Guarnaccia, C.; Tajani, F.; Di Liddo, F.; Anelli, D. An analysis of the noise pollution influence on the housing prices in the central area of the city of Bari. J. Phys. Conf. Ser. 2020, 1603, 12027. [CrossRef]

3. Mabee, W.; Blair, J.; Carlson, J.; Deloyde, C. Sustainability. In International Encyclopedia of Human Geography, 2nd ed.; Kobayashi, A., Ed.; Elsevier: Amsterdam, The Netherlands, 2020; pp. 157-163. Available online: https:/ /www.sciencedirect.com/referencework/ 9780081022962/international-encyclopedia-of-human-geography (accessed on 8 November 2021).

4. Ko, T.G. Development of a tourism sustainability assessment procedure: A conceptual approach. Tour. Manag. 2005, 26, 431-445. [CrossRef]

5. Hosseini, K.; Stefaniec, A.; Hosseini, S.P. World Heritage Sites in developing countries: Assessing impacts and handling complexities toward sustainable tourism. J. Destin. Mark. Manag. 2021, 20, 100616. [CrossRef]

6. Wang, S.-X.; Lu, W.-M.; Hung, S.-W. You gain when you give: Constructing a sustainable development model for world heritage sites. J. Clean. Prod. 2021, 328, 129547. [CrossRef]

7. European Commission. Sustainability and Cultural Heritage. Available online: https://ec.europa.eu/culture/cultural-heritage/ cultural-heritage-in-eu-policies/sustainability-and-cultural-heritage (accessed on 20 October 2021).

8. Leygraf, C.; Wallinder, I.O.; Tidblad, J.; Graedel, T. Atmospheric Corrosion; John Wiley \& Sons: Hoboken, NJ, USA, 2016.

9. Oliveira, M.L.S.; Neckel, A.; Silva, L.F.O.; Dotto, G.L.; Maculan, L.S. Environmental aspects of the depreciation of the culturally significant Wall of Cartagena de Indias-Colombia. Chemosphere 2021, 265, 129119. [CrossRef]

10. Artesani, A.; di Turo, F.; Zucchelli, M.; Traviglia, A. Recent advances in protective coatings for cultural heritage-An overview. Coatings 2020, 10, 217. [CrossRef]

11. García-Florentino, C.; Maguregui, M.; Carrero, J.A.; Morillas, H.; Arana, G.; Madariaga, J.M. Development of a cost effective passive sampler to quantify the particulate matter depositions on building materials over time. J. Clean. Prod. 2020, 268, 122134. [CrossRef]

12. Camuffo, D. Weathering of building materials. In Urban Pollution and Changes to Materials and Building Surfaces; Brimblecombe, P., Ed.; World Scientific: Singapore, 2016; pp. 19-64.

13. Bolaño-Truyol, J.; Schneider, I.L.; Cuadro, H.C.; Bolaño-Truyol, J.D.; Oliveira, M.L.S. Estimation of the impact of biomass burning based on regional transport of PM2.5 in the Colombian Caribbean. Geosci. Front. 2021, 13, 101152. [CrossRef]

14. Chen, X.; Zhang, S.; Ruan, S. Polycentric structure and carbon dioxide emissions: Empirical analysis from provincial data in China. J. Clean. Prod. 2021, 278, 123411. [CrossRef]

15. Silva, L.F.O.; Milanes, C.; Pinto, D.; Ramirez, O.; Lima, B.D. Multiple hazardous elements in nanoparticulate matter from a Caribbean industrialized atmosphere. Chemosphere 2020, 239, 124776. [CrossRef] [PubMed]

16. Morillas, H.; Marcaida, I.; Maguregui, M.; Upasen, S.; Gallego-Cartagena, E.; Madariaga, J.M. Identification of metals and metalloids as hazardous elements in PM2.5 and PM10 collected in a coastal environment affected by diffuse contamination. J. Clean. Prod. 2019, 226, 369-378. [CrossRef]

17. Morcillo, M.; de la Fuente, D.; Díaz, I.; Cano, H. Atmospheric corrosion of mild steel. Rev. Metal. 2011, 47, 426-444. [CrossRef]

18. Morillas, H.; Maguregui, M.; Gallego-Cartagena, E.; Marcaida, I.; Carral, N.; Madariaga, J.M. The influence of marine environment on the conservation state of Built Heritage: An overview study. Sci. Total Environ. 2020, 745, 140899. [CrossRef] [PubMed]

19. Screpanti, A.; de Marco, A. Corrosion on cultural heritage buildings in Italy: A role for ozone? Environ. Pollut. 2009, 157, 1513-1520. [CrossRef] [PubMed]

20. Sabbioni, C.; Cassar, M.; Brimblecombe, P.; Tidblad, J.; Kozlowski, R.; Drdácký, M.; Saiz-Jimenez, C.; Grøntoft, T.; Wainwright, I.; Ariño, X. Global climate change impact on built heritage and cultural landscapes. In Proceedings of the International Conference on Heritage, Weathering and Conservation, HWC 2006, Madrid, Spain, 21-24 June 2006; pp. 395-401. 
21. Brimblecombe, P.; Grossi, C.M.; Harris, I. Climate change critical to cultural heritage. In Survival and Sustainability; Gökçekus, H., Türker, U., LaMoreaux, J.W., Eds.; Springer: Berlin/Heidelberg, Germany, 2010; pp. 195-205.

22. Grossi, C.M.; Brimblecombe, P.; Harris, I. Predicting long term freeze-Thaw risks on Europe built heritage and archaeological sites in a changing climate. Sci. Total Environ. 2007, 377, 273-281. [CrossRef]

23. Brimblecombe, P. Heritage climatology. In Climate Change and Cultural Heritage; Lefevre, R.-A., Sabbioni, C., Eds.; Edipuglia: Bari, Italy, 2010.

24. de la Fuente, D.; Vega, J.M.; Viejo, F.; Díaz, I.; Morcillo, M. City scale assessment model for air pollution effects on the cultural heritage. Atmos. Environ. 2011, 45, 1242-1250. [CrossRef]

25. Tidblad, J.; Kucera, V.; Mikhailov, A.A.; Henriksen, J.; Kreislova, K.; Yates, T.; Stöckle, B.; Schreiner, M. UN ECE ICP materials: Dose-response functions on dry and wet acid deposition effects after 8 years of exposure. In Acid Rain 2000; Satake, K., Shindo, J., Takamatsu, T., Nakano, T., Aoki, S., Fukuyama, T., Hatakeyama, S., Ikuta, K., Kawashima, M., Kohno, Y., et al., Eds.; Springer: Dordrecht, The Netherlands, 2001; pp. 1457-1462.

26. Mikhailov, A.A.; Tidblad, J.; Kucera, V. The classification system of ISO 9223 standard and the dose-Response functions assessing the corrosivity of outdoor atmospheres. Prot. Met. 2004, 40, 541-550. [CrossRef]

27. Ríos-Rojas, J.F.; Aperador-Rodríguez, D.; Hernández-Garcia, E.A.; Arroyave, C.E. Annual atmospheric corrosion rate and dose-response function for carbon steel in Bogotá. Atmósfera 2017, 30, 53-61. [CrossRef]

28. Tidblad, J.; Kucera, V.; Samie, F.; Schreiner, M.; Melcher, M.; Kreislova, K.; Knotkova, D.; Lefèvre, R.A.; Ionescu, A.; Snethlage, R.; et al. MULTI-AS-SESS, Publishable Final Report, 2005, Model for Multi-Pollutant Impact and Assessment of Threshold Levels for Cultural Heritage. Available online: https:/ / www.ri.se/sites/default/files/2021-04/ICP-MULTI-ASSESS-Publishable-finalreport.pdf (accessed on 8 November 2021).

29. Broomandi, P.; Tleuken, A.; Zhaxylykov, S.; Nikfal, A.; Kim, J.R.; Karaca, F. Assessment of potential benefits of traffic and urban mobility reductions during COVID-19 lockdowns: Dose-response calculations for material corrosions on built cultural heritage. Environ. Sci. Pollut. Res. 2021, 1-20. [CrossRef]

30. Watt, J.; Jarrett, D.; Hamilton, R. Dose-response functions for the soiling of heritage materials due to air pollution exposure Sci. Total Environ. 2008, 400, 415-424. [CrossRef] [PubMed]

31. Watt, J.; Tidblad, J.; Kucera, V.; Hamilton, R. (Eds.) The Effects of Air Pollution on Cultural Heritage; Springer: Boston, MA, USA, 2009; Volume 6.

32. de la Fuente, D.; Vega, J.M.; Viejo, F.; Díaz, I.; Morcillo, M. Mapping air pollution effects on atmospheric degradation of cultural heritage. J. Cult. Herit. 2013, 14, 138-145. [CrossRef]

33. Spezzano, P. Mapping the susceptibility of UNESCO World Cultural Heritage sites in Europe to ambient (outdoor) air pollution. Sci. Total Environ. 2021, 754, 142345. [CrossRef] [PubMed]

34. Zhang, X.; Zhou, L.; Wu, Y.; Skitmore, M.; Deng, Z. Resolving the conflicts of sustainable world heritage landscapes in cities: Fully open or limited access for visitors? Habitat Int. 2015, 46, 91-100. [CrossRef]

35. Srijuntrapun, P. A Sustainable Livelihood Approach in a World Heritage Area. Ph.D. Thesis, Lincoln University, Ayutthaya, Thailand, 2012.

36. Pearce, D.W.; Mourato, S. The Economic of Cultural Heritage, World Bank Support to Cultural Heritage Preservation in the MNA Region; Centre for Social and Economic Research on the Global Environment (CSERGE), University College London: London, UK, 1998.

37. Artal-Tur, A. Culture and cultures in tourism. Anatolia 2018, 29, 179-182. [CrossRef]

38. Richards, G. Cultural tourism: A review of recent research and trends. J. Hosp. Tour. Manag. 2018, 36, 12-21. [CrossRef]

39. Frey, B.S.; Briviba, A. A policy proposal to deal with excessive cultural tourism. Eur. Plan. Stud. 2021, 29, 601-618. [CrossRef]

40. Artal-Tur, A.; Villena-Navarro, M.; Alamá-Sabater, L. The relationship between cultural tourist behaviour and destination sustainability. Anatolia 2018, 29, 237-251. [CrossRef]

41. Du Cros, H.; McKercher, B. Cultural Tourism; Routledge: London, UK, 2020. [CrossRef]

42. Lee, H. Cultural Tourism. Ann. Tour. Res. 2016, 57, 286-288. [CrossRef]

43. Tunbridge, J.E.; Ashworth, G.J.; Graham, B.J. Decennial reflections on A Geography of Heritage (2000). Int. J. Herit. Stud. 2013, 19, 365-372. [CrossRef]

44. Page, S. A Geography of Heritage: Power, Culture and Economy: By Brian Graham, G.J. Ashworth and J.E. Tunbridge. N. Z. Geogr. 2000, 56, 61-62. [CrossRef]

45. Timothy, D.J. Cultural Heritage and Tourism: An Introduction Channel View 2021. Available online: https://www.degruyter. com/document/doi/10.21832/9781845417727/html (accessed on 8 November 2021).

46. Silva, H.E.; Henriques, F.M.A. The impact of tourism on the conservation and IAQ of cultural heritage: The case of the Monastery of Jerónimos (Portugal). Build. Environ. 2021, 190, 107536. [CrossRef]

47. World Travel \& Tourism Council. Economic Impact Reports. Travel \& Tourism—Global Economic Impact E Trends 2020. Available online: https:/ / wttc.org/Research/Economic-Impact (accessed on 8 November 2020).

48. Mazzanti, M. Cultural heritage as multi-dimensional, multi-value and multi-attribute economic good: Toward a new framework for economic analysis and valuation. J. Socio. Econ. 2002, 31, 529-558. [CrossRef]

49. Dümcke, C.; Gnedovsky, M. The Social and Economic Value of Cultural Heritage: Literature Review; EENC Paper; European Expert Network on Culture (EENC), 2013; pp. 1-114. Available online: https://www.interarts.net/descargas/interarts2557.pdf. (accessed on 8 November 2020). 
50. Nuryanti, W. Heritage and postmodern tourism. Ann. Tour. Res. 1996, 23, 249-260. [CrossRef]

51. Pindyck, R.S.; Rubinfeld, D.L. Microeconomics, 4th ed.; Prentice Hall: Upper Saddle River, NJ, USA, 1998.

52. Rojas, E.; de Moura Castro, C. Lending for Urban Heritage Conservation: Issues and Opportunities; No. 3839; Inter-American Development Bank: Washington, DC, USA, 1999. Available online: https://publications.iadb.org/en/publication/lendingurban-heritage-conservation-issues-and-opportunities (accessed on 7 November 2021).

53. Bowitz, E.; Ibenholt, K. Economic impacts of cultural heritage-Research and perspectives. J. Cult. Herit. 2009, 10, 1-8. [CrossRef]

54. Corpoturismo. El Turismo, el Empleo que Crece 3 Veces Más Rapido que Otros Sectores. Available online: http: / / www.cartagenadeindias.travel/corporacion-institucional_sitcar-5?la=es\&/noticia-ampliada_en-turismo-el-empleo-crece-3veces-ms-rpido-que-otros-sectores-784 (accessed on 10 March 2020). (In Spanish).

55. Zuleta, L.A.; Jaramillo, L. Cartagena de Indias, Impacto Económico de la Zona Histórica; Convenio Andrés Bello: Bogotá, Colombia, 2006; Volume 13. (In Spanish)

56. Galvis-Aponte, L.A.; Aguilera-Díaz, M.M. Determinantes de la Demanda por Turismo Hacia Cartagena, 1987-1998; Documentos de Trabajo Sobre Economía Regional y Urbana; No. 9; 1999. Available online: https://dialnet.unirioja.es/descarga/articulo/483384 0.pdf (accessed on 6 November 2021). (In Spanish) [CrossRef]

57. Baéz, J. Impacto Economico de la Realización de los XX Juegos Centroamericanos y del Caribe en la Ciudad de Cartagena; Universidad de Cartagena. Planeación Distrital: Cartagena, Colombia, 2002. Available online: https://biblio.flacsoandes.edu.ec/libros/digital/ 54978.pdf (accessed on 6 November 2021). (In Spanish)

58. Vaughan, D.R. The cultural heritage: An approach to analyzing income and employment effects. J. Cult. Econ. 1984, 8, 1-36. [CrossRef]

59. Murzyn-Kupisz, M. The socio-economic impact of built heritage projects conducted by private investors. J. Cult. Herit. 2013, 14, 156-162. [CrossRef]

60. Mules, T. Regional economic impacts of tourism in heritage mining towns. In Heritage Economics. Challenges for Heritage Conservation and Sustainable Development in the 21st Century; Australian Heritage Commission: Canberra, Australia, 2000.

61. Mourato, S.; Mazzanti, M. Economic valuation of cultural heritage: Evidence and prospects. In Assessing the Values of Cultural Heritage; de la Torre, M., Ed.; Getty Conservation Institute: Los Angeles, CA, USA, 2002. Available online: https://www.getty. edu/conservation/publications_resources/pdf_publications/pdf/assessing.pdf (accessed on 8 November 2021).

62. ICOMOS. International Seminar of Ibero-American Historical Cities (CIHIB). Available online: www.esicomos.org/Nueva carpeta/libroTOLEDO/49_conclusiones.htm (accessed on 7 November 2021).

63. Centro de Investigaciones Oceanográficas e Hidrográficas (CIOH). Climatología de los principales puertos del Caribe Colombiano -Cartagena de Indias, D.T. y C. Available online: https:/ / www.cioh.org.co/meteorologia/Climatologia/Climatologia/Cartagena. pdf (accessed on 15 May 2021). (In Spanish).

64. Padaui, F.B. (Ed.) Valoración de los Niveles de Riesgos Ambientales en el Distrito de Cartagena; Instituto de Hidráulica de Saneamiento Ambiental de la Universidad de Cartagena. 2014. Available online: https:/ / www.researchgate.net/profile/EdgarQuinones-Bolanos/publication/284284893_Valoracion_de_los_niveles_de_riesgos_ambientales_en_el_Distrito_de_Cartagena_ de_Indias/links/5651087f08ae4988a7abc4cf/Valoracion-de-los-niveles-de-riesgos-ambientales-en-el-Distrito-de-Cartagenade-Indias.pdf (accessed on 7 November 2021).

65. ISO. ISO 9225:2012Corrosion of Metals and Alloys-Corrosivity of Atmospheres-Measurement of Environmental Parameters Affecting Corrosivity of Atmospheres, ISO: Geneve, Switzerland, 2012.

66. National Ocean Service. What are El Niño and La Niña? Available online: https://oceanservice.noaa.gov/facts/ninonina.html (accessed on 22 April 2021).

67. Euscátegui, C.; Hurtado, G. Análisis del Impacto del Fenómeno La Niña 2010-2011 en la Hidroclimatología del País; IDEAM; (In Spanish). Available online: http:/ / www.ideam.gov.co/documents/21021/418818/Analisis+Impacto+La+Ni na.pdf/640a4a18-4a2a-4a2 5-b7d5-b3768e0a768a (accessed on 10 October 2021).

68. Ministro de Ambiente y Desarrollo Sostenible. Resolución 2254 de 2017 Ministerio del Medio Ambiente. 2017. Available online: https://www.google.com.hk/url?sa=t\&source=web\&rct=j\&url=https://www.minambiente.gov.co/wp-content/uploads/20 21/08/resolucion-2267-de-2018.pdf\&ved=2ahUKEwiMqPivwfz0AhXTIDQIHS9nAwwQFnoECDIQAQ\&usg=AOvVaw3Vjw6 NSU4P9Di6c7li6f5L (accessed on 10 October 2021).

69. Beydoun, M.A.; Popkin, B.M. The impact of socio-economic factors on functional status decline among community-dwelling older adults in China. Soc. Sci. Med. 2005, 60, 2045-2057. [CrossRef]

70. Mazzanti, M. Valuing cultural heritage in a multi-attribute framework microeconomic perspectives and policy implications. J. Socio. Econ. 2003, 32, 549-569. [CrossRef]

71. Tupėnaite, L.; Naimavičienė, J.; Bagdonavičius, A.; Sabaliauskas, K. Management of Construction and Real Estate Under Conditions of Market Instability; VGTU Press TECHNIKA: Vilnius, Lithuania, 2015.

72. Kucera, V. Model for Multi-Pollutant Impact and Assessment of Threshold Levels for Cultural Heritage; Swedish Corrosion Institute: Stockholm, Sweden, 2005.

73. Vega, C.A.B. Evaluación de la Corrosividad de Atmósferas Colombianas y su Impacto Sobre el Deterioro de Algunos Materiales Empleados en el Sector Eléctrico; Universidad de Antioquia: Medellin, Colombia, 2008; p. 166. (In Spanish)

74. Restrepo Carvajal, A.H. Impacto de la Corrosión Atmosférica del Aluminio y el Cobre en la Infraestructura del Sector Eléctrico Colombiano; Universidad de Antioquia: Medellin, Colombia, 2008; p. 170. 
75. Ministerio. de Ambiente y Desarrollo Sostenible. con apoyo de Ministerio de Minas Y Energía, Norma Nacional de Calidad de Combustible Diesel y Biodiesel. 2019; p. 15. Available online: https://www.minenergia.gov.co/documents/10192/24104363 / Ana\%EClisis+de+Impacto+Normativo+06062019_MinAmbiente+\%2528GMR\%2529_GAU2+\%25281\%2529.pdf/f9c3b013-ba0 c-48cb-b617-a8b6561bc3a7 (accessed on 4 October 2021).

76. Vidal, F.; Vicente, R.; Silva, J.M. Review of environmental and air pollution impacts on built heritage: 10 questions on corrosion and soiling effects for urban intervention. J. Cult. Herit. 2019, 37, 273-295. [CrossRef]

77. Salas, E. Informe Calidad de Vida 2020. Available online: http://www.cartagenacomovamos.org/nuevo/wp-content/uploads/ 2020/09/Informe-Calidad-de-Vida-2020-Cartagena-Como-Vamos.pdf (accessed on 7 November 2021).

78. Rosales, B.M.; Almeida, M.E.M.; Morcillo, M.; Uruchurtu, J.; Marrocos, M. Corrosión y Protección de Metales en las Atmosferas de Iberoamérica; CYTED, Gráficas Salué: Madrid, Spain, 1999.

79. Ambler, H.R.; Bain, A.A.J. Corrosion of metals in the tropics. J. Appl. Chem. 1955, 5, 437-467. [CrossRef]

80. Morcillo, M.; Chico, B.; Mariaca, L.; Otero, E. Salinity in marine atmospheric corrosion: Its dependence on the wind regime existing in the site. Corros. Sci. 2000, 42, 91-104. [CrossRef]

81. Saba, M.; Quiñones-Bolaños, E.E.; Batista, H.F.M. Impact of environmental factors on the deterioration of the Wall of Cartagena de Indias. J. Cult. Herit. 2019, 39, 305-313. [CrossRef]

82. Fernández, M.C.; Herrera, A.B.C. La preservación de centros históricos: Análisis situacional de Cartagena de Indias. Amauta 2017, 15, 85-101. (In Spanish) [CrossRef]

83. UNESCO. List of Factors Affecting the Properties. Available online: https://whc.unesco.org/en/factors/ (accessed on 2 November 2021).

84. Coccossis, H. Sustainable development and tourism: Opportunities and threats to cultural heritage from tourism. In Cultural Tourism and Sustainable Local Development; Routledge: London, UK, 2016; pp. 65-74.

85. McLoughlin, J.; Sodagar, B.; Kaminski, J. Dynamic socioeconomic impact: A holistic analytical framework for cultural heritage sites. In Heritage Impact 2005, Proceedings of the First International Symposium on the Socio-economic Impact of Cultural Heritage; Archaeolingua: Budapest, Hungary, 2005; pp. 43-57. Available online: http:/ / public-repository.epoch-net.org/publications / heritageimpact/heritageimpact.pdf (accessed on 8 November 2020).

86. Ashworth, G. The commodification of the past as an instrument of local development: Do not count on it. In Heritage Impact 2005, Proceedings of the First International Symposium on the Socio-economic Impact of Cultural Heritage; Archaeolingua: Budapest, Hungary, 2005; pp. 81-88.

87. Sirisrisak, T. Conservation of Bangkok old town. Habitat Int. 2009, 33, 405-411. [CrossRef]

88. Yung, E.H.K.; Zhang, Q.; Chan, E.H.W. Underlying social factors for evaluating heritage conservation in urban renewal districts. Habitat Int. 2017, 66, 135-148. [CrossRef]

89. Grazuleviciute-Vileniske, I.; Urbonas, V. Architectural heritage as a socioeconomic opportunity for revitalization of historic urban centres: A global perspective. Archit. Urban Plan. 2011, 5, 27-37.

90. Zadel, Z.; Bogdan, S. Economic impact of cultural tourism. UTMS J. Econ. 2013, 4, 355-366. 